\title{
Investigation on the effect of date of sowing on the incidence of defoliator pests of sunflower
}

\author{
SYED MUZAMMIL*, A.P. BIRADAR AND N. SHRUTHI \\ Department of Agricultural Entomology, College of Agriculture (U.A.S.), VIJAYAPUR (KARNATAKA) INDIA
}

\section{ARITCLE INFO}

Received : 24.01 .2017

Revised : 20.02.2017

Accepted : 25.02.2017

\section{KEY WORDS :}

Sunflower, Sowing dates, Defoliator pests, Per cent foliage damage,

Natural enemies

*Corresponding author:

Email:muzzujasu930@gmail.com

\begin{abstract}
A field experiment was conducted during the Kharif/Rabi season of 2014 in Regional Agriculture Research Station (RARS) to identify the appropriate sowing time to reduce pest incidence and to get higher seed yield. The sunflower hybrid, KBSH-53 recorded highest seed yield ( $12.95 \mathrm{q} / \mathrm{ha}$ and $12.05 \mathrm{q} / \mathrm{ha}$ ) with reduced pest incidence and per cent foliage damage during the crop sown on first fortnight of September and second fortnight of August as compared to the crop sown on second fortnight of September, first fortnight of October and second fortnight of October.
\end{abstract}

How to view point the article : Muzammil, Syed, Biradar, A.P. and Shruthi, N. (2017). Investigation on the effect of date of sowing on the incidence of defoliator pests of sunflower.. Internat. J. Plant Protec., 10(1) : 1-6, DOI : 10.15740/HAS/LJPP/10.1/1-6. 